Info Artikel

Diterima : 27 Juli 2019

Disetujui : 29 Januari 2020

Dipublikasikan : 29 Januari 2020

\title{
Penerapan Model Group Investigation (GI) dalam Pembelajaran Menulis Teks Eksposisi Kelas VIII SMP PGRI Pagar Alam Tahun Pelajaran 2018/2019
}

\author{
Rani Agustina $^{1 \bowtie}$, Henny Nopriani ${ }^{\circledR 凶}$ \\ STKIP Muhammadiyah Pagar Alam \\ raniagustina2343@gmail.com,nopriai_henny@yahoo.com
}

\begin{abstract}
Writing exposition text occupies an important role in learning to write. This is because exposition writing is a process of explaining or giving meaning to writing styles that are concise, concise, and accurate. The purpose of this study was to determine the results of the application of the group investigation (GI) model in learning to write exposition text class VIII SMP PGRI Pagar Alam 2018/019. The population is 230 people. The research sample was taken with the aim of only 1 class, namely class VII.4, amounting to 30 people. Data collection techniques in this study are performance tests for writing exposition text. The results showed that by applying the group investigation model (GI) in writing the exposition text of class VIII4 SMP PGRI Pagar Alam an average value of 85.5 was obtained.
\end{abstract}

Keywords: text, exposition, investigation model

Abstrak: Menulis teks eksposisi menduduki peraanan penting dalam pembelajaran menulis. Hal ini disebabkan menulis eksposisi adalah suatu proses untuk menjelaskan atau memberikan pengertian dengan gaya penulisan yang singkat, padat, dan akurat. Tujuan penelitian ini untuk mengetahui hasil penerapan model group investigation (GI) dalam pembelajaran menulis teks eksposisi kelas VIII SMP PGRI Pagar Alam Tahun 2018/019. Populasi berjumlah 230 orang. Sampel penelitian ini diambil secara bertujuan hanya 1 kelas yaitu kelas VII.4 yang berjumlah 30 orang. Teknik pengumpulan data dalam penelitian ini yaitu tes unjuk kerja menulis teks eksposisi. Hasil penelitian menunjukkan bahwa dengan menerapkan model group investigatio (GI) dalam menulis teks eksposisi kelas VIII4 SMP PGRI Pagar Alam dapat diperoleh nilai rata-rata 85.5.

Kata Kunci: teks, eksposisi, model investigasi

Sitasi Jurnal:

Agustina, R., \& Nopriani, H. (2020). Penerapan Model Group Investigation (GI) dalam Pembelajaran Menulis Teks Eksposisi Kelas VIII SMP PGRI Pagar Alam Tahun Pelajaran 2018/2019. Disastra: Jurnal Pendidikan Bahasa dan Sastra Indonesia, 2(1), 68-74. doi:http://dx.doi.org/10.29300/disastra.v2i1.2063 


\section{Pendahuluan}

Pembelajaran bahasa Indonesia bertujuan meningkatkan kemampuan intelektual, emosional, sosial, dan mampu meningkatkan pengetahuan serta kemampuan berbahasa (Aulia, 2019). Sekalipun keterampilan menulis merupakan keterampilan yang paling sulit bagi siswa, namun kurikulum mengharuskan siswa untuk terampil mengusai keterampilan tersebut tanpa mengabaikan keterampilan berbahasa yang lainnya (Efnawarty, 2019). Salah satu materi dalam pembelajaran Bahasa Indonesia adalah menulis teks eksposisi. Keterampilan menulis teks eksposisi diajarkan kepada siswa dengan tujuan agar siswa mampu menulis teks eksposisi dengan bahasa yang baik dan benar serta koheren sesuai dengan karakteristik teks. Untuk menjadikan sebuah teks eksposisi menjadi sebuah paparan penjelasan yang informatif, maka teks eksposisi harus dikembangkan dengan menggunakan fakta.

Menulis teks eksposisi terdapat dalam silabus kurikulum 2013 SMP kelas VIII semester 2 pada kompetensi inti (KI-4) mengolah dan menyaji dalam ranah konkret (menggunakan, mengurai, merangkai, memodifikasi, dan membuat) dan ranah abstrak (menulis, membaca, menghitung, menggambar, dan mengarang) sesuai dengan yang dipelajari di sekolah dan sumber lain yang sama dalam sudut pandang/teori. Kompetensi dasar (KD-4.6) menyajikan gagasan dan pendapat ke dalam bentuk teks eksposisi berupa artikel ilmiah populer (lingkungan hidup, kondisi sosial, dan/atau keragaman budaya.) secara lisan dan tertulis dengan memperhatikan struktur, unsur kebahasaan, dan aspek lisan.

Berdasarkan hasil angket yang disebarkan di SMP PGRI Pagar Alam tanggal 5 Maret 2019 terdapat beberapa permasalahan. Pertama, siswa kesulitan menentukan ide dalam menulis teks eksposisi. Kedua, siswa kesulitan dalam menuliskan teks eksposisi yang sesuai dengan struktur teks eksposisi

Sejalan dengan hasil angket dari sisw. Hasil angket guru 5 Maret 2019 juga menunjukan kalau siswa terdapat kesulitan dalam menulis teks eksposisi sebagai berikut: 1) siswa kesulitan dalam menentukan ide, 2) siswa sulit untuk mengarang sebuah teks eksposisi sesuai dengan struktur teks eksposisi.

Dalman (2018) memaparkan bahwa menulis merupakan suatu kegiatan komunikasi untuk menyampaikan pesan kepada pembaca dalam bentuk bahasa tulis. Sehingga kesulitan-kesulitan yang dihadapi siswa, tentu harus mempunyai solusi yang tepat agar siswa dapat menulis teks eksposisi dengan tepat. Salah satunya, adalah dengan menerapkan model pembelajaran. Adanya model-model baru yang bermunculan sebenarnya membuat siswa menjadi lebih aktif. Guru berperan sebagai fasilitator demi tercapainya tujuan belajar. Model-model pembelajaran yang dapat diterapkan adalah satunya adalah model group investigation (GI).

Model group Investigation merupakan strategi belajar kooperatif yang menempatkan siswa ke dalam kelompok untuk melakukan investigasi terhadap suatu topik. Model group investigation memberikan kesempatan seluas-luasnya kepada siswa untuk terlibat secara langsung 
dan aktif dalam proses pembelajaran mulai dari perencanaan samapai cara mempelajari suatu topik melalui suatu investigasi (Huda, 2017).

Dengan model ini (1) dapat memecahkan permasalahan yang dihadapi siswa. (2) dapat merangsang ide-ide kreatif siswa, kemudian membangun konsep ideide kreatif tersebut menjadi sebuah teks sehingga akan mudah dalam menulis teks eksposisi. (3) dapat membantu siswa dalam menuangkan ide-idenya menjadi sebuah teks karena dalam pembelajaran siswa merefleksikan pengalaman-pengalaman yang telah mereka alami sehingga kejadian tersebut terjadi saat ini juga.

Model group investigation ini lebih menekankan pada pilihan dan kontrol siswa daripada menerapkan teknik-teknik pengajaran di ruang kelas. Dalam model group investigation, siswa diberi kontrol dan pilihan penuh untuk merencanakan apa yang ingin dipelajari dan diinvestigasi. Pertamatama siswa ditempatkan dalam kelompokkelompok kecil. Masing-masing kelompok diberi tugas dan bekerja sama dengan kelompoknya.

Huda (2017) menyatakan langkahlangkah pembelajaran group investigation (GI) ada tiga tahap, antara lain (1) siswa harus memiliki kelompok; (2) siswa memiliki rencana koopratif; dan (3) peran guru. Dalam group investigation (GI) ini siswa diajarkan untuk bekerja sama dan berinteraksi antar siswa. Pembelajaran yang dilakukan mengharuskan siswa untuk secara langsung melakukan penyelidikan terhadap objek atau peristiwa yang akan diteliti. Dalam hal ini salah satu model pembelajaran group investigation (GI) cocok digunakan dalam menulis teks eksposisi.
Kurniasih (2015) menjelaskan bahwa kelebihan model pembelajaran group investigation (GI), yaitu sebagai berikut. (1) Penerapan model ini mempunyai pengaruh yang positf, yaitu dapat meingkatkan motivasi belajar siswa. (2) Pembelajaran yang dilakukan membuat suasana saling bekerjasama dan berinteraksi antar siswa dalam kelompok tanpa memandang latar belakang. (3) Model ini juga melatih siswa untuk memiliki kemampuan yang baik untuk berkomunikasi dan mengemukakan pendapatnya.(4) Memotivasi dan mendorong siswa agar aktif dalam proses belajar mulai dari tahap pertama sampai tahap akhir pembelajaran.

Alasan peneliti memilih judul penerapan model group investigation (GI) dalam menulis teks eksposisi tersebut, yaitu mempunyai implikasi yang positif terhadap pengembangan keterampilan, penemuan, dan membantu mencapai tujuan serta untuk memahami secara mendalam terhadap suatu topik yang dilakukan melalui investigasi, serta melatih agar bekarja secara kooperatif dalam memecahkan suatu masalah. Jadi menerapkan model group investigation (GI) dapat belajar dengan penemuan, belajar isi dan belajar bekerjasama secara kooperatif.

\section{Metode Penelitian}

Metode yang digunakan dalam penelitian ini yaitu metode deskriptifkuantitatif. Metode penelitian deskriptif digunakan untuk mendeskripsikan penerapan model group investigation dalam pembelajaran menulis teks eksposisi siswa kelas VIII SMP PGRI Pagar Alam. Kuantitatif digunakan untuk mengukur nilai rata-rata hasil tes penerapan model group investigation dalam pembelajaran menulis 
teks eksposisi siswa kelas VIII SMP PGRI Pagar Alam.

Populasi adalah keseluruhan objek penelitian. Apabila seseorang ingin meneliti semua elemen yang ada dalam wilayah penelitian, maka penelitiannya merupakan penelitian populasi (Arikunto,2010).

Sampel adalah bagian dari jumlah dan karakteristik yang dimiliki oleh populasi tersebut (Sugiyono, 2011). Teknik pengambilan sampel yang digunakan dalam penelitian ini adalah porposive sampling yaitu pengambilan sampel berdasarkan keperluan penelitian, artinya setiap unit yang diambil dari popolasi dipilih dengan sengaja berdasarkan pertimbagan tertentu. Sampel dalam penelitian ini adalah siswa kelas VIII SMP PGRI 1 Pagar Alam tahun pelajaran 2018-2019 yang berjumlah 30 .

Teknik pengumpulan data yang digunakan dalam penelitian ini adalah tes dan observasi. Tes adalah pertanyaan atau latihan alat lain yang digunakan untuk mengukur keterampilan intergrasi, kemampuan yang dimiliki indivindu atau kelompok (Arikunto, 2010). Tes yang digunakan dalam penelitian yaitu unjuk kerja menulis teks eksposisi.

Observasi sebagai pengumpulan data mempunyai ciri yang spesifik bila dibandingkan dengan yang lain, yaitu wawancara dan kuesioner. Kalau wawancara dan kuesioner selalu berkomunikasi dengan orang, maka observasi tidak terbatas pada orang, tetapi juga objek-objek alam yang lain. Obsevasi dalam penelitian ini yaitu menggunakan koesiner yang dibagikan dengan mahasiswa.

Langkah-langkah teknik analisi data dalam penelitian ini adalah sebagai berikut
1) Data skor hasil tes dianalisis dengan melihat skor hasil tes siswa dalam menulis teks eksposisi.

2) Data tes diidentifikasi dan diklasifikasikan.

3) Data tes dianalisis secara deskriptif dalam bentuk perhitungan kuantitatif.

4) Selanjutnya, setelah diberi skor dengan menggunakan rubrik penilaian di atas. Hasil kerja siswa dalam menyusun teks ekspsosisi dapat menggunakan rumus di bawah ini

$$
\text { skor }=\frac{\text { Jumlah skor yang didapat }}{\text { Skor maksimal }} \times 100
$$

Artinya tingkat pengusaan yang diperoleh:

\begin{tabular}{|l|l|l|}
\hline No. & \multicolumn{1}{|c|}{ Kategori } & $\begin{array}{l}\text { Rentang } \\
\text { Sekor }\end{array}$ \\
\hline 1. & Sangat baik & $85-100$ \\
\hline 2. & Baik & $70-84$ \\
\hline 3. & Cukup & $60-69$ \\
\hline 4. & Kurang & $50-59$ \\
\hline 5. & Sangat Kuarang & $<5$ \\
\hline
\end{tabular}

(Djumingin, 2017).

\section{Hasil Penelitian dan Pembahasan}

Hasil menulis teks eksposisi dengan menerapakan model Groub Investigation dapat dilihat pada tabel 1 di bawah ini.

Tabel 1

\section{Rekapitulasi Nilai Menulis Teks \\ Eksposisi}

\begin{tabular}{|c|c|c|c|}
\hline No & $\begin{array}{c}\text { Nilai yang } \\
\text { didapat siswa }\end{array}$ & $\begin{array}{c}\text { Jumlah } \\
\text { Siswa }\end{array}$ & Jumlah \\
\hline 1 & 74 & 4 & 296 \\
\hline 2 & 75 & 1 & 75 \\
\hline 3 & 78 & 2 & 156 \\
\hline 4 & 79 & 7 & 553 \\
\hline 5 & 80 & 1 & 80 \\
\hline 6 & 81 & 6 & 486 \\
\hline 7 & 82 & 1 & 82 \\
\hline
\end{tabular}




\begin{tabular}{|c|c|c|c|}
\hline 8 & 85 & 1 & 85 \\
\hline 9 & 89 & 1 & 89 \\
\hline 10 & 90 & 3 & 270 \\
\hline 11 & 91 & 3 & 273 \\
\hline & & 30 & 2445 \\
\hline \multicolumn{3}{|c|}{ Nilai rata-rata } & 81,5 \\
\hline
\end{tabular}

Hasil menulis teks eksposisi dengan menerapkan Group Investigation nilai ratarata siswa dalam pembelajaran menulis teks eksposisi di SMP PGRI Pagar Alam dapat dikatakan berhasil. Hal ini dapat dilihat dari nilai rata-rata yang diperoleh yaitu 81,5 termasuk kata kategori baik, keberhasilan dari subjek penelitian adalah $20 \%$.

Selanjutnya, rincian skor dari aspek penilaian dapat dilihat pada tabel di bawah ini.

Tabel 2

Skor Penilian Kesesuaian Jenis Teks

\begin{tabular}{|c|c|c|c|c|}
\hline No. & $\begin{array}{l}\text { Aspek yang } \\
\text { Dinilai }\end{array}$ & Skor & $\begin{array}{l}\text { Jumlah } \\
\text { Siswa }\end{array}$ & $\begin{array}{l}\text { Skor } \\
\text { Tota } \\
1\end{array}$ \\
\hline \multirow[t]{3}{*}{1.} & \multirow{3}{*}{$\begin{array}{l}\text { Kesesuaian } \\
\text { jenis teks }\end{array}$} & 24 & 8 & 192 \\
\hline & & 22 & 8 & 176 \\
\hline & & 21 & 14 & 294 \\
\hline \multicolumn{2}{|c|}{ Jumlah } & 25 & 30 & 662 \\
\hline \multicolumn{2}{|c|}{ Skor rata-rata } & \multicolumn{3}{|c|}{$=\frac{662}{30}=22,07$} \\
\hline \multicolumn{2}{|c|}{ Nilai rata-rata } & \multicolumn{3}{|c|}{$\frac{22,07}{25} \times 100=88,28$} \\
\hline
\end{tabular}

Berpedoman perolehan rata-rata pada tabel 2 di atas, diperoleh nilai rata-rata aspek penilaian kesesuaian teks eksposisi adalah 88,28. Berdasarkan kategori hasil belajar nilai dikategorikan baik.

\section{Tabel 3}

Skor Penilaian Tesis

\begin{tabular}{|l|l|c|c|c|}
\hline No. & $\begin{array}{l}\text { Aspek } \\
\text { yang } \\
\text { Dinilai }\end{array}$ & Skor & $\begin{array}{l}\text { Jumlah } \\
\text { siswa }\end{array}$ & $\begin{array}{l}\text { Skor } \\
\text { total }\end{array}$ \\
\hline 1. & Tesis & 23 & 7 & 161 \\
\cline { 2 - 5 } & & 20 & 8 & 160 \\
\hline
\end{tabular}

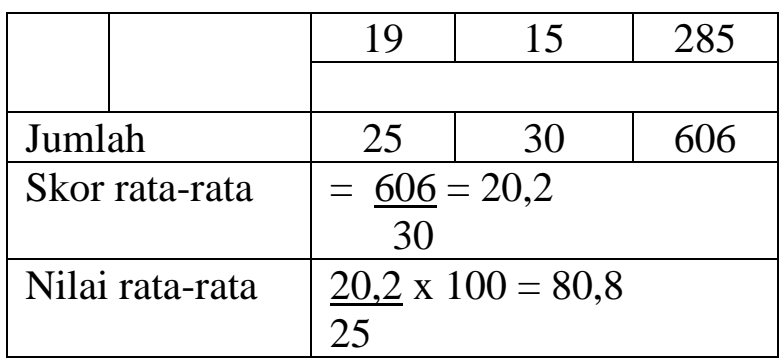

Berpedoman perolehan rata-rata pada tabel 3 di atas, diperoleh nilai rata-rata aspek penilaian tesis adalah 80,8 . Berdasarkan kategori hasil belajar nilai dikategorikan baik.

\section{Tabel 4}

Skor Penilaian Argumen

\begin{tabular}{|l|l|c|c|c|}
\hline No. & $\begin{array}{l}\text { Aspek } \\
\text { yang } \\
\text { Dinilai }\end{array}$ & Skor & $\begin{array}{l}\text { Jumlah } \\
\text { Siswa }\end{array}$ & $\begin{array}{l}\text { Skor } \\
\text { Total }\end{array}$ \\
\hline \multirow{2}{*}{1.} & Argumen & 23 & 3 & 69 \\
\cline { 3 - 5 } & 22 & 4 & 88 \\
\cline { 3 - 5 } & 20 & 16 & 320 \\
\cline { 3 - 5 } & 19 & 7 & 133 \\
\hline Jumlah & 25 & 30 & 610 \\
\hline Skor rata-rata & \multicolumn{2}{|l|}{$\frac{610}{30}=20,33$} \\
\hline Nilai rata-rata & \multicolumn{2}{|l|}{$20,33 \times 100=81,32$} \\
\hline
\end{tabular}

Berpedoman perolehan rata-rata pada tabel 4 di atas, diperoleh nilai rata-rata aspek penilaian kesesuian teks eksposisi adalah 81,32. Berdasarkan kategori hasil belajar nilai dikategorikan baik.

Tabel 5

Skor Penilaian Penegasan Ulang

\begin{tabular}{|l|l|c|c|c|}
\hline No. & $\begin{array}{l}\text { Aspek yang } \\
\text { Dinilai }\end{array}$ & Skor & $\begin{array}{l}\text { Jumlah } \\
\text { siswa }\end{array}$ & $\begin{array}{l}\text { Skor } \\
\text { total }\end{array}$ \\
\hline \multirow{2}{*}{1.} & $\begin{array}{l}\text { Penegasan } \\
\text { ulang }\end{array}$ & 21 & 10 & 210 \\
\cline { 3 - 5 } & 19 & 15 & 285 \\
\cline { 3 - 5 } & 15 & 5 & 75 \\
\cline { 2 - 5 } & \multicolumn{3}{|l}{} \\
\hline \multicolumn{2}{|l|}{ Jumlah } & \multicolumn{2}{|l|}{30} & 570 \\
\hline \multicolumn{2}{|l|}{ Skor rata-rata } & \multicolumn{3}{|l}{} \\
\hline
\end{tabular}


Nilai rata-rata

$$
\frac{19}{25} \times 100=76
$$

Berpedoman perolehan rata-rata pada 5 di atas, diperoleh nilai rata-rata aspek penilaian kesesuian teks eksposisi adalah 76. Berdasarkan kategori hasil belajar nilai dikategorikan baik.

Selanjutnya, observasi dilakukan selasa, 05 Maret 2019. Pada saat penelitian menjelaskan pembeljaran dengan menggunakan model group investigation (GI). Observsi ini dilakukan oleh guru sebagai observer, dengan menggunakan model group investigation (GI). Dari hasil obsevasi peneliti mendapatkan skor 80 dengan kategori baik.

Berdasarkan hasil observasi yang dilakukan oleh guru mata pelajaran Bahasa Indonesia terhadap peneliti, dalam menerapkan model group investigatio (GI) dalam menulis teks eksposisi siswa kelas VIII.4 SMP PGRI Pagar Alam dikategorikan baik. Dari hasil penelitian yang dilakukan oleh observasi dengan menggunakan lembar observasi, diperoleh nilai rata-rata 80 , ini berarti kemampuan peneliti menggunakan model group investigatio (GI) sudah baik.

Selanjutnya, berdasarkan hasil tes menulis teks eksposisi dengan menerapkan model group investigatio (GI) di kelas VIII.4 SMP PGRI Pagar Alam mendapatkan nilai rata-rata 81,5 dengan kategori baik.

\section{Simpulan}

Dari pembahasan di atas, dapat ditarik simpulan bahwa bahwa hasil observasi yang dilakukan oleh guru mata pelajaran Bahasa Indonesia terhadap peneliti, dalam menerapkan model group investigatio (GI) untuk menulis teks eksposisi siswa kelas VIII.4 SMP PGRI

Pagar Alam dikategorikan baik.

Selanjutnya, berdasarkan hasil tes menulis dengan menerapkan model group investigatio (GI) dalam menulis teks eksposisi kelas VIII.4 SMP PGRI Pagar Alam dapat dikategorikan baik.

Keberhasilan ini disebabkan beberapa faktor yaitu: pertama penerapan model group investigatio (GI) dalam menulis teks eksposisi berlangsung dengan baik. Kedua karena pembelajaran menulis teks eksposisi dilakukan secara berkelompok agar siswa lebih percaya diri dan dapat mengembangkan ide saat menulis teks eksposisi (Huda, 2017).

\section{Daftar Pustaka}

Arikunto, S. (2010). Prosedur Penelitian Suatu Pendekatan Praktik Kompetensi. Yogyakarta: BPFE.

Aulia, W. (2019). Korelasi Penguasaan Kosakata Dengan Keterampilan Menulis Eksposisi Siswa Kelas Xi Sma Negeri 03 Kota Bengkulu. Disastra: Jurnal Pendidikan Bahasa Dan Sastra Indonesia, 1(2), 35. https://doi.org/10.29300/disastra.v1i 2.1902

Dalman. (2015). Keterampilan Menulis. Jakarta: PT Rajagrapindo Presada.

Djumingin. (2017). Teks Eksposisi dan Perangkatnya. Makasar: Universitas Negeri Makasar.

Efnawarty, E. (2019). Peningkatan Kemampuan Menulis Teks Diskusi Dengan Menggunakan Model Kooperatif Learning Tipe Debat Pada Siswa Kelas Viii H Smp Negeri 1 Rejang Lebong. Disastra: Jurnal Pendidikan Bahasa Dan Sastra Indonesia, $\quad 1(2), \quad 78$. https://doi.org/10.29300/disastra.v1i 
2.1903

Huda, M. (2017). Model-Model Pembelajaran. Jakarta: pustaka belajar.

Kurniasih, I. (2015). Model Pembelajaran. Tanpa tempat terbit: Kata pena.
Volume 1, Nomor 2, Juli 2019 ISSN 2655-3031 (P), 2655-7851 (O)

Sugiyono. (2018). Metode penelitian Pendidikan:Pendekatan Kuantitatf dan $R \& D$, Penerbit Alfabeta. Bandung. 